Faculdade de Ciências Econômicas UFRGS
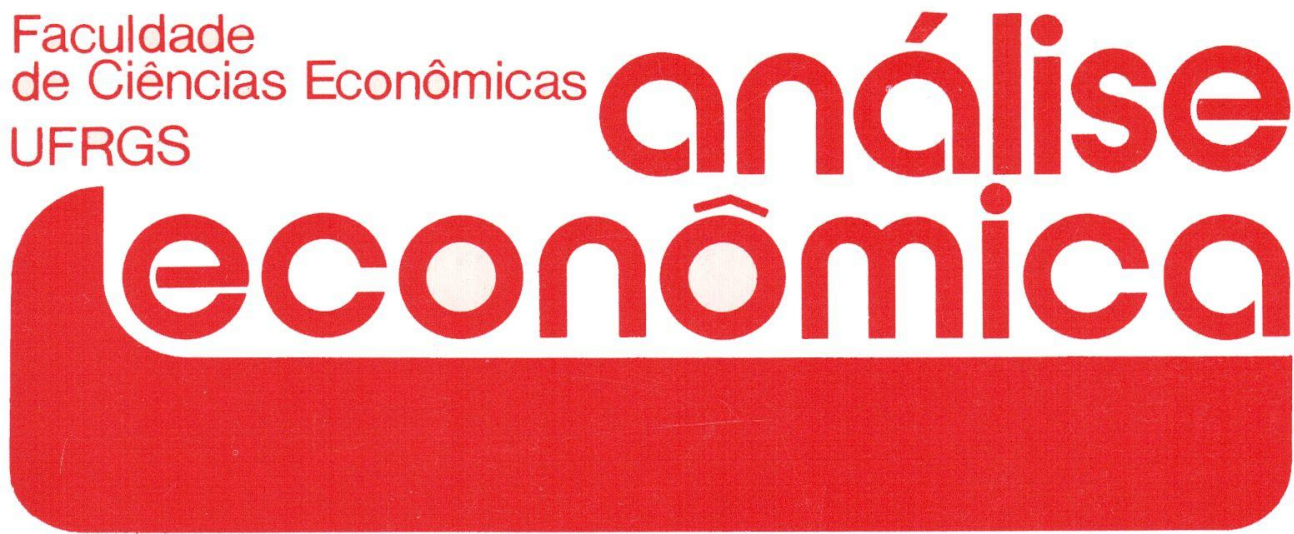

- STATE AND THE LIBERALIZATION OF THE BRAZILIAN ECONOMY

Carlos Alberto Longo

- MOEDA E CRÉDITO NA ECONOMIA BRASILEIRA: UM MODELO COM VETORES DE CORREÇÃO DE ERROS

Rolando M. Guzmán

- baSES PARA UM NOVO MOdELO DE POLítica FISCAL, PARA O BRASIL

Flávio Riani

- POR QUE OS SINOS DOBRAM? CONFLITO TRABALHISTA E SALÁRIOS DO MAGISTÉRIO PÚBLICO DO RIO GRANDE DO SUL, 1974-1991

Carlos Henrique Horn

Roberto Balau Calazans

- A POLÍtica MONETÁRIa E AS TAXAS de JUROS NO PLANO COLLOR

Lauro Lobo Burle

- DIFUSÃo E TRANSFERÊNCIA DA TECNOLOGIA DE PRODUÇÃO DE CIMENTO NO BRASIL

Maria Cristina Pereira de Melo

- SISTEMA FINANCEIRO BRASILEIRO: UMA PROPOSTA dE disCuSSÃo

Luiz Felipe Serpa

- TEORIA ECONÓMICA DO CASAMENTO E DO Divórcio

Giácomo Balbinotto Neto

- RESENHA

VARGAS: O CAPITALISMO EM CONSTRUÇÃO, DE PEDRO C. D. FONSECA

João Rogério Sanson

- LIVROS RECEBIDOS

Claudine Saldanha César
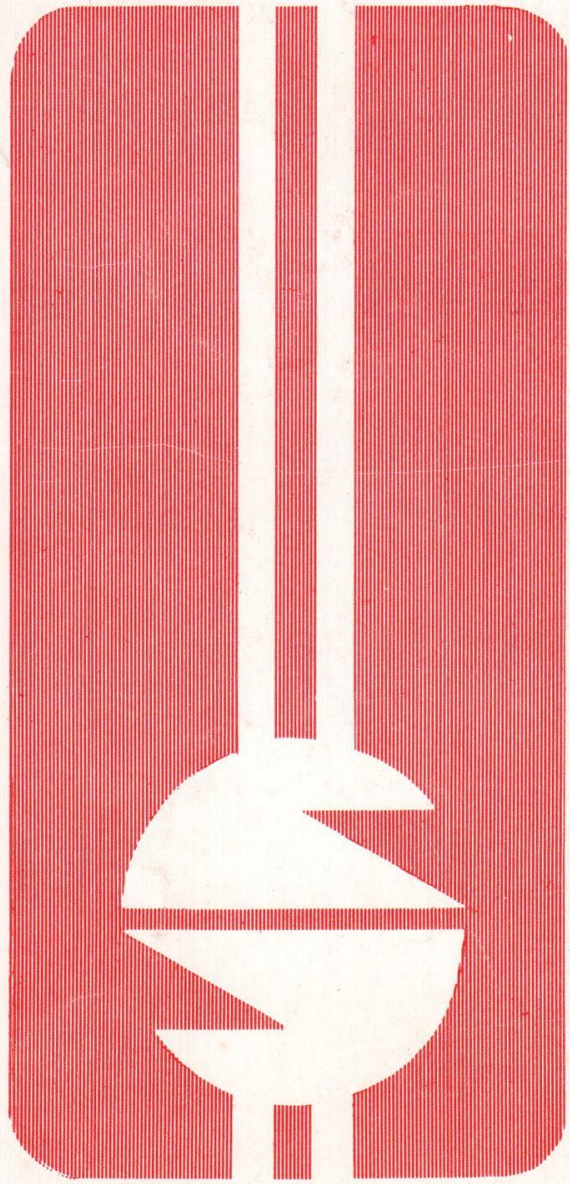
UNIVERSIDADE FEDERAL DO RIO GRANDE DO SUL

Reitor: Prof. Hélgio Henrique Casses Trindade

FACULDADE DE CIÉNCIAS ECONÔMICAS

Diretora: Prof ${ }^{a}$ Yeda Rorato Crusius

CENTRO DE ESTUDOS E PESQUISAS ECONÔMICAS

Diretor: Reinaldo Ignacio Adams

DEPARTAMENTO DE CIENNCIAS ECONÔMICAS

Chefe: Prof. Fernando Ferrari Filho

CURSO DE PÓS-GRADUAÇÃO EM ECONOMIA

Coordenador: Prof. João Rogério Sanson

CURSO DE PÓS-GRADUAÇÃO EM ECONOMIA RURAL

Coordenador: Prof. Juvir Luiz Mattuella

CONSELHO EDITORIAL: Achyles Barcelos da Costa, Aray Miguel Feldens, Atos Freitas Grawunder, Carlos Augusto Crusius, ErnaniHickmann, Fernando Ferrari Filho, João Rogério Sanson, Juvir Luiz Mattuella, Maria Imilda da Costa e Silva, Nali de Jesus de Souza, Nuno Renan Lopes de Figueiredo Pinto, Otília Beatriz Kroeĩ Carrion, Otto Guilherme Konzen, Paulo Alexaridre Spohr, Pedro Cezar Dutra Fonseca, Reinaldo Ignacio Adams, RobertsCamps Moraes, Valter José Stülp, Yeda Rorato Crusius, David Garlow (Wharton Econometrics Forecasts Association, E.U.A.), Edgar Augusto Lanzer (UFSC), Eleutério F. S. Prado (USP), Fernando Holanda Barbosa (FGV/RJ), Gustavo Franco (PUC/RJ), Joaquim Pinto de Andrade (UiNB), Juan H. Moldau (USP), Werner Baer (Univ. de Illinois, E.U.A.)

COMISSÃO EDITORIAL: Atos Freitas Grawunder, Reinaldo Ignacio Adams, Pedro Cezar Dutra Fonseca, Roberto Camps Moraes.

EDITOR: Nali Jesus de Souza

SECRETARIA: Maria Ivone de Mello (normalização), Vanete Ricacheski (revisão de textos)

FUNDADOR: Prof. Antônio Carlos Santos Rosa

Os materiais publicados na Revista Análise Econômica são de exclusiva responsabilidade dos autores. É permitida a reprodução total ou parcial dos trabalhos, desde que seja citada a fonte.

Aceita-se permuta com revistas congêneres. Aceitam-se, também, livros para divulgação, elaboração de resenhas ou recensões.

Toda correspondência, material para publicação (vide normas na $3^{a}$ capa), assinaturas e permutas devem ser dirigidos ao seguinte destinatário:

PROF. NALI DE JESUS DE SOUZA

Revista Análise Econômica

Av. João Pessoa, 52

90040-000 - PORTO ALEGRE (RS), BRASIL

Telefones: (051) 228.1633 - 224.6022 - Ramais 3348 ou 3440

FAX: (051) 225.1067 


\title{
STATE AND THE LIBERALIZATION OF THE BRAZILIAN ECONOMY*
}

\author{
Carlos Alberto Longo**
}

\begin{abstract}
This paper argues that the last stabilization plan that succeded in Brazil coincided with the institutional reforms wich took place in 1964/65 under the Castello Branco administration. These changes gave way to a decade of high economic growth that ended abruptely. Errors of policy decision in 1979/80 and later during the Sarney administration, paved the way to the stagflation of the eighties. Strutural macro disiquilibrium resulted in the erosion of public revenues and large debt arrears which compromised the efficacy of monetary and fiscal policies. Many at tempts to stabilize the price level and change institutions during the Collor administration failed due to inconsistent policy targets and lack of a well designed development plan. Not matched by permanent fiscal adjustments and major structual refurms the observed advances in the litsralization, privatization, and deregulation programs may be aborted and lead to wasteful disindustrialization.
\end{abstract}

\section{INTRODUCTION}

This paper examines the Brazilian perspectives under the current revisionist tendency of the role of the State and the integration of national economies. In order to understand the causes and consequences of recent efforts to stabilize and liberalize the economy, a brief historical background is presented, bringing together the 1964/65 major structural reforms, the strategic mistakes of 1979/80 and the opportunities !ost under the Sarney administration. A diagnosis of institutional flaws inherited from previous governments is introduced where the need to descentralize revenues and expenditures of federal entities, as well as of the national Treasury, is discussed. The text follows with an analysis of current

* This paper was originaly prepared for the conference "Brazil: The Challenges of the 1990s", Institute of Latin American Studies, University of London, Oct 31/Nov. 1, 1991. Subsequent revision and update took place in March 1992.

** Department of Economics, University of São Paulo, Brazil.

ANÁLISE ECONÔMICA

\begin{tabular}{l|l|l|} 
ANO 10 & $\mathrm{~N}: 18$ & SETEMBRO/92 \\
\hline
\end{tabular}

P.3-23 
economic policies aimed at the control of prices and the level of activity covering the first two years of the Collor administration. The paper concludes with a description and evaluation of the privatization, deregulation and liberalization programs.

\section{HISTORICAL BACKGROUND}

The last time a stabilization plan succeeded in Brazil was during the administration of Marshal Humberto de Alencar Castello Branco (1964-67). The government's economic action programme (PAEG) managed to hold inflation down to $70 \%$ in 1964 , although it had been set to reach $140 \%$ in the year by March, when the military took power. In 1965 the annual rate came down still further to about $35 \%$, and from there on it continued to drop until it reached $14 \%$ in 1972 . Like all comprehensive anti-inflation plans, the PAEG was based on a threepronged strategy that combined fiscal, monetary and incomes" policy targets (Simonsen, 1970).

On that occasion the federal government remodelled its budget so as to reduce the fiscal deficit to $\mathrm{Cr} \$ 753$ million in 1964, whereas this deficit had originally been expected to rise to $\mathrm{Cr} \$ 2$ billion. The actual deficit in the period was $\mathrm{Cr} \$ 748$ million. At the same time the government undertook to restrict monetary expansion in 1964 to $\mathrm{Cr} \$ 2$ billion, which would mean a $70 \%$ increase in this aggregate compared with the preceding year. The actual rate of growth in the money supply was $85 \%$. Thus this was not a radical stabilization programme designed to balance the budget at all costs, but it was explicit enough not to give rise to any doubt about the government's intentions or the direction in which fiscal and monetary policies were moving. As a result, the recession was not profound. Income per head and industrial output, both of which had been flat since 1963, began rising sharply from 1967 on. The crisis reached its height in 1965, when industrial output dropped almost 5\% (Pelaez \& Suzigan, 1976, p. 336-67).

The programme acknowledged the need for a gradualistic incomes policy. Hitherto, real wages had swung sharply between peaks and troughs due to high inflation and the long intervals between wage adjustments (two years). Instead of calculating wage adjustments so as to restore purchasing power to its previous peak, the new policy instituted a formula whereby the average real wage during the 12-month period in which the newly adjusted nominal rate was to remain in force would be equal to the average real wage in the preceding 24 months.

Alongside the price stabilization programme, the government paved the way for far-reaching changes in the structure of the tax and financial systems. Among many advances and innovations it is worth highlighting the replacement of IVC (Imposto sobre Vendas e Consignações) with ICM (Imposto sobre a Circulação de Mercadorias), the bank reform (Law 4595 of December 1964), the creation of the Housing Finance System (SFH) and of the indexation system known as monetary correction (Law 4380 of August 1964), and regulation of the capital market (Law 
4728 of July 1965). The argument is often heard that these reforms were made easier to implement by the absence of political constraints under military rule. The truth is however that harsh criticism was openly directed against the federal executive, both in Congress and by influential state governors (São Paulo, Minas Gerais and Guanabara). Moreover, plans for institutional reform had been made public, and draft legislation covering these questions had been sent to Congress well in advance.

After the Castello Branco administration (1964-67), no subsequent administration made a frontal assault on inflation. Hence, over the ensuing 20 -year period inflation rates rose steadily as a result of surges in demand or supply. Limited attempts to implement contractionist policies proved failures because of virtually total indexation of prices and incomes, making inflationary expectations highly inelastic: fiscal or monetary contraction had limited impact on inflation but led to recession, which was then politically injudicious.

The administration that took office in 1967 decided it would be inadvisable to continue with policies designed to reduce demand. It set itself the goal of promoting economic growth and full employment, despite the fact that inflation was still high at $25 \%$ per annum. To some extent, this "developmentalist" position taken by President Costa e Silva (1967-69), and sustained by President Garrastazú Médici (1969-74), was motivated by the opportunity for an upswing in the economy created by the austerity measures and institutional reforms implemented under the previous administration.

The first Development Plan (lst PND) adopted in 1969 consolidated and extended the import-substitution model introduced by President Jascelino Kubitschek (1955-60) but this time placed the emphasis on exports. Instead of the liberalizing framework of the PAEG, it put its trust in central planning and state interveniion in the economy. Indexation through the monetary correction mechanism vas extended to all markets, prices were submitted to government control (trough CONEP, and later CIP), the PAEG's rules for wage adjustment were maintained, credit controls were introduced, and interest ratcs capped. The econom: programme introduced in 1969 achieved all its aims: high levels of production and employment, a foreign trade surplus, and inf!ation stabilized at about $20 \%$ per annum.

The price paid for this performance (the "Brazilian miracle"), was that relative prices were straitjacketed by monetary correction and excessive state intervention in the economy. Wide-ranging, generous tax and credit subsidies favored agriculture, exports and industry. Ownership became concentrated in the banking industry, the Central Bank lost its independence, and the official banks became directly subordinated to the Finance Ministry. State-owned enterprises occupied the gaps not yet filled by private enterprise.

During the Geisel administration (1974-79) economic policy frequently changed tack under the pressure of circumstances, especially the inertial inflation inherited from the previous administration and aggravated by the first oil shock. In view of the ineffectiveness of conventional economic policy instruments, the 
government chose to accommodate to the external shock by increasing inflation. The vicious circle created by indexation of prices, wages and exchange-rates, with structural balance-of-payments deficits, was alleviated by the abundance of cheap external credit and by compression of prices and rates charged by SOEs.

The main goal of the second Development Plan (2nd PND) was to proceed with the import-substitution development model, especially in heavy industry, fine chemicals, pulp and paper, and to launch an ambitious programme of investment in energy and infrastructure commanded by the state but funded with foreign loans. Implementation of this policy was backed by the same instruments as those employed by the previous government, such as control of prices, wages, foreign exchange and credit. Major distortions in relative prices began to emerge. Domestic demand was buoyed up by subsidies to public-service charges and credit, designed to boost consumption and production. Financing of the balance-ofpayments deficit depended crucially on relending of foreign loans underwritten by the Treasury.

The second oil shock (1979) and the refusal of developed-country governments to accommodate to rising domestic inflation brought Brazil face to face with a severe dilemma in the early 1980s. The chalienge was to restrict aggregate demand, realigning relative prices and temporarily accept low rates of economic growth with high unemployment. The fatal mistake made by the Figueiredo administration (1979-85) was to press on with the now outdated development programme initiated in the previous decade. The argument used was that Brazil was different, that through public investment, subsidies to import-substituting industries (Proálcool, coal, and petroleum prospecting) and preferential treatment for exports of natural resources (agricultural products such as soybeans and orange juice, and primary goods such as ores) it would be possible to go on growing despite the new external constraints and internal distortions inherited from previous governments.

Brazil began the 1980 s, in fact, without any planning fromework at all. In the abcence of explicit performance targcts, and with increasingly weak instruments of government action, the Executive made even more extensive and intensive use of the auministrative controls available. It centralized control of public expenditurc and merged into a single consolidated agency - SEST (Secretaria Especial de Controle das Empresas Estatais) - all operations relating to the financing of SOEs and official banks. It created more systems for monitoring and controlling prices and wages (CIP, SEAP, SUNAB, SISE). It stepped up the frequency with which the rules of the game were unexpectedly and suddenly changed, for example by setting the monetary correction and exchange rates in advance (i. e. not indexing them to actual inflation), by announcing massive one-off devaluations of the cruzeiro, and by changing the mechanism for wage adjustment. The result of this opoportunistic, illmanaged policy was steadily rising inflation and a prolonged recession (1980-83). 
In the mid-1980s another historic opportunity to point economic policy in a new direction presented itself. Once again, however, the government preferred facile measures that guaranteed its popularity, summed up in the motto of the Sarney administration, "Tudo pelo social". Under President José Sarney (198590), the government recognized that combating inflation must be an end in itself. Yet its stabilization plans also contained major flaws, both in conceptual terms (Cruzado Plan) and in implementation (Bresser Plan, Summer Plan). The nation had not yet become accustomed to the tug-of-war between contending forces that is typical of democracy. The federal administration's shortsightedness and incompetence were compounded by the inexperience of Congress, and even of the law courts, which failed to present constructive suggestions for solutions to the succession of crises linked to the attempts at stabilization of the economy.

With the economy teetering on the brink of hyperinflation, President Fernando Collor took office announcing bold measures to contain the price spiral, implement institutional reform and improve social welfare. It is no secret, however, that these objectives cannot be attained overnight but result from a long process with its own intrinsically necessary chronology. The first step must be to wipe the slate clean of past errors; next, the rate of growth can be stepped up; and finally it will be possible to distribute the benefits of higher growth. Thus, while economic policy makers during the "economic miracle" were able to capitalize on the effects of the austerity measures and reforms implemented by the Castello Branco administration, in the 1980 s, despite the manifestly populist intentions of governments, they lacked the wherewithal for fulfilling their promises.

\section{THE STATE AS "ENTREPRENEUR"1}

A pragmatic approach to the analysis of the functions of the state consists of weighing up the costs and benefits of its presence in the economy. The quality of the public sector depends on the effectiveness of its component parts - central, state and municipal governments, official banks and state-owned enterprises. However, obscure fiscal and financial relationships not only distort the application of funds by the state but actually make it impossible to identify how such funds are used. ${ }^{2}$

SOEs are often used as instruments of stabilization policy, with the Treasury as controlling shareholder and the official banks as the main source of financing. Interbudgetary transfers can take the form of loans, capital increases or subsidies.

1 An expanded version of the arguments in this section can be found in Longo $\left(1990^{\circ}\right)$; Longo $\left(1990^{b}\right)$ e Longo (1992).

2 The budgetary obscurity thai results from cross-subsidies between the fiscal budget and state enterprises is characteristic of many developing, newly-industrialized countries. For a comparative analysis, grounded in statistical information and accompanied by suggestions for reform. see World Bank (1988). But this problem is not confined to developing nations; it permeates discussions of deregulation and privatization in Western Europe and the socialist countries. See for example the case of the USSR Senchagov(1989). 
The way the transfer is classified for accounting purposes does not necessarily correspond to the economic nature of the operation. Capital transfers (loans and investment) are frequently transformed into current transfers (subsidies) during the fiscal year. Thus when SOEs are turned into an instrument of macroeconomic policy, the budgetary process fails to provide clear-cut information as to the nature and effective availability of the funds to which it refers. As a result, the elaboration and evaluation of the 'Treasury budget becomes a process of aggregation, which combines central guidelines regarding the scarcity of funds on the one hand with requirements for financing SOEs on the other. (Premchand, 1988).

A major criticism of the development model adopted by Brazil is that state participation in the economy is excessive. Clientism, corporatism and the absence of stimuli for private investment are among the basic causes of the state's insolvency. There are not even enough funds available to cover the simplest, most everyday items of public spending, and wages have been incessantly depressed by the decline in investment.

The mismatch between public revenue and expenditure is largely determined by long-standing commitments inherited from previous administrations. The consolidated budget procedure recently adopted by the federal Executive failed to eliminate several sources of long-teîm disequilibrium. The Executive's draft budget currently being debated by Congress is no more than a desperate attempt to contain the fiscal deficit by means of arbitrary hikes in taxes and tariffs. The exhaustion of the traditional sources for financing the public deficit explains the failure of so many stabilization plans.

Structural disequilibrium derives from the excessive indebtedness of the public sector, meaning all three spheres of government, together with the respective state-owned enterprises and financial institutions. No clear definition exists as to who is legally accountable for these liabilities, and it is therefore virtually impossible to formulate a set of alternative solutions. Systematic transfer of funds (in current and capital budgets) from one part of the public sector to cover default or government guarantee of a debt in another is not compatible with proper budgetary and administrative practice.

There is an urgent need for attributions in the public sector to be clearly discriminated so as to prevent the present situation of interlocking arrears and cross-defaults between agencies from jeopardizing operational efficiency and increasing the fiscal deficit. The concern here is of both a microeconomic and an aggregate nature. It is difficult to envisage any possibility of administrative rationality in production and selling of goods and services when prices are controlled by the Finance Ministry and levels of indebtedness by the Central Bank. In this case, the cash flow of SOEs is defined in terms of what is usually called the "national interest". As a result, priorities are not set with a view to protecting the "interests of the consumer" (quality and price) or those of the shareholder (profit). 


\section{ATTEMPTS AT STABILIZATION ${ }^{3}$}

\subsection{1st Collor Plan}

The essence of the Collor Plan centered on three presidential decrees, known as Provisional Measures under the federal constitution of Brazil; issued in March 1990 , these contained a set of fiscal, monetary and incomes policies. Other parts of the Plan (civil service and administrative reforms, cutbacks in subsidies, action to eradicate tax evasion, sales of government property, privatization of SOEs) can be considered complementary in character: they may eventually come to represent the New Brazil (Collor's election slogan) but in isolation they hold little significance with regard to the success or failure of the stabilization programme.

Price and wage hikes were forbidden. To help balance the budget, publicservice charges and prices of key SOEs goods were raised, as was the Financial Operations Tax (levied on money market transactions, among others). The sharp drop in inflation also contributed. The initial effectiveness of the plan was guaranteed by an immediate reduction of liquidity. Only about a quarter of all financial assets remained at the disposal of the public. Inflationary expectations were abruptly reversed.

The weak points of the plan were excessive centralization, violation of property rights, and a high degree of risk. The government could have avoided these drawbacks without impairing the effectiveness of the plan if instead it had opted for modernizing the instruments of economic policy and empowering other decision-making bodies. For example, the Central Bank remained unindependent, Congress was not informed of the Executive's budget projections, and the Judiciary was obliged to perform veritable feats of legal acrobatics, for the benefit of a plan which contemplated neither second thoughts nor second opinions.

Rather than reprogramming the budget it had inherited from the Sarney administration and seeking an agreement with Brazil's creditors, Collor's team chose to resont to drastic measures designed to balance revenue and expenditure as quickly as possible. New taxes were created, along with surcharyes and compulsory loans, in addition to the seizure of liquid assets: these measures were both inadvisable and of doubtful legality. Moreover, their social cost can be evaluated in retrospect, in that the sacrifices imposed were in vain because inflation is again running at a high level.

It is difficult to appraise the real fiscal situation of the federal sector, since budgets are either out of date or non-existent. Furthermore, the excessive financial interpenetration of the various public entities confuses priorities and discourages sound application of funds. The only consistent source of information is the federal

3 For a less shematic presentation of the Collor Plan and related issues, see L.ongo (1990), Longo (199 la) e L.ongo (1991b). 
treasury's cash flow statement, but since this does not discriminate clearly between the rights and obligations of different jurisdictions it cannot be taken as an indicator of permanent balance in the budget.

The return of high inflation after three months is attributable in the cost side to the government's decision to adjust public-sector and other prices for inflation occurring in the period. But on the demand side, pressure had also built up owing to the exacerbation of inflationary expectations, despite the drop in the level of economic activity. People were beginning to realize, from the observation of a number of macroeconomic indicators, that the government was losing control of its stabilization program three monts after the Collor Plan was announced.

By August, the crass errors committed in implementing the measures in the first two or three months had led to a $10 \%$ rise in prices. Difficulties in communicating with the business community, the law courts and Congress, and delays in negotiations on foreign debt rescheduling were examples of the government's growing inability to conduct the stabilization programme effectively. Indeed, it is not enough to reduce inflation by decree, ensure that the treasury has a balanced cash flow, allow interest rates to rise to unprecedented heights, and at the same time lift import restrictions. This is a familiar approach, which proved a failure in Pinochet's Chile and in Argentina under Finance Minister Martinez de Hoz.

The risk cf opening up the economy too fast and providing excessive incentives to investors in the. financial market, typically accompanied by overvaluation of the local currency, is that decapitalization and obsolescence wiil ensue for domestic industry, with only limited gains on the inflation front and severe social costs in terms of job losses and wasted production.

\subsection{2nd Collor Plan}

Impatient with developments in the economy, the Executive launched in January 1991 another incomplete and overhasty economic package. Regrettably, it did nothing to compensate for the succession of errors committed during implementation of the 1 st Collor Plan. The 2nd plan again consisted almost entirely of measures entailing ? high degree of risk and a high social cost - a sharp hike in public-sector prices, another freeze on wages and prices, and a set of complicated changes in the rules for financial markets. This second attempt to stabilize the currency was claimed to be an "extension" or "deepening" of the first. The irony is that the government's claim was not altogether unfounded, for Plan II achieved little more than a repetition of the initial failure to stamp out inflation for good and all.

In every respect the style, form and substance of the initiatives associated with the 2nd Collor Plan were similar to those of the previous package. With regard to style, the Executive again behaved in an overweening and arbitrary manner. It abruptly changed the rules of the game without any prior consultations aimed to 
seek the comprehension, let alone the support, of organized social groups and representative institutions (the Legislative and Judiciary). As to form, the new package consisted of another batch of Provisional Measures, presidential decrees and Central Bank resolutions, very similar to the approach adopted the first time around.

No financial equilibrium could be expected to result from such chaotic, arbitrary initiatives as postponements of payment, seizure of funds, or raising of taxes and duties. Definitive reprogramming of expenditure would have entailed the questioning of rights and obligations, job security, social security benefits, sharing out ou tax revenues among the three tiers of government, and the relations between the federal Executive, SOEs and monetary authorities.

The measures introduced by de federal Executive ignored, and in many cases actually infringed, accepted principles of administrative decentralization and tax prerogatives. They failed to undertake a comprehensive review of the management, instruments and aims of the federal administration. They failed to pay due respect to the institutions of republican government - in short, to share power. Thus the Collor administration failed to improve on the fiscal and monetary policies followed by its predecessers.

\subsection{Change of Style}

The Collor administration's disastrous conduct of the economy in its first year of office was matched by the lack of confidence deposited in the Executive (verging on deadlock, if not direct confrontation) by the other two branches of government, and by both labour and industry. These misgivings were a reaction tothe prevalence until May 1991 of voluntaristic, incoherenteconomic policymaking and target setting.

Genuine structural reforms of the public sector were not pursued. The Executive focused its attention on combating inflation and utilized short-term terhniques to tiis end. It did not concern itself, for example, with undertaking a tax reform, consolidating the budgetary process or overhauling the financial system. Instead, it swiftly and expeditiously seized assets, froze prices, altered indicators and arrested tax evaders.

The legacy of these two stabilization plans was mediocre. There was a need to rethink the meaning and utility of such pyrotechnical innovations in the financial market as the "Fundão" (money fund, i.e. overnight balances that must be kept in standardize funds) and TR (taxa referencial, i.e. indexed bonds that substituted for the official "reference" rate of interest). A market solution had to be found for the excessively regulated financial sector. Today, disintermediation in the corporate and financial investments is becoming as prevalent as it was in the early 1960 s.

When the federal administration suddenly shifted to what it called a "soft" style in May 1991, it was reacting to the widespread perception that the country 
was becoming ungovernable. Congress was anyway reluctant to ratify any more of the Executive's Provisional Measures; the Supreme Court had put a stop to the outgoing economic team's insistence on dubious legal manuevering by granting more and more restraining orders to annul the effect of the two plans. Thus, the balance of power between the three branches of government had apparently been restored.

As price and exchange controls were lifted, the economy slowly moved to free market. This time, with no risk of hyperinflation, as there was after the price freezes imposed by stabilization plans in the past. Prices were raised not for speculative reasons but to adjust to repressed costs. For the time being, demand remains suppressed because wages are low and liquidity is tight. Inflacion in still rising, albeit more slowly.

The problem is how to administer the wage-price spiral in the absence of reliable inflation indices (due to a law which prohibits indexation in the short run). The search must now begin for a means of avoindig universal informal indexation. Thus the solution for the Collor administration will have to reside in yet another stabilization plan. It is likely that as the second half of the year wears on, the Executive will change its management of aggregate demand, this time on the basis of a general review of public finances.

Inflation remains high and shows no signs of a downturn of any significance in the coming months. The fact that the curve has flattened out does not prevent speculation about future acceleration. The pessimistic scenario in based on the idea that little has been done to solve the structural disequilibrium in public-sector finances.

The managerial flaws of the Collor administration to date have led to a lack of confidence in its program. There is no disagreement of note with the general direction of economic policy-trade liberalization, monetary austerity, privatization of state-owned enterprises etc. But the results achieved so far have been minimal and costly. Besides having failed to make progress with its so-called major reforms, the government frequently iinds itself bogged down in Congress and the Judiciary over initiatives of an essentially short-term nature, such as emergency economic measures, extension of maiturities for state and municipal debts to the federal sphere, or increases in social security contributions.

It is possible to identify several inconsistencies. First, there is the question of timing. Lifting of price controls, opening up the economy and privatizations must all be properly cocrdinated, temporally speaking, with the actual (as opposed to announced) start of institutional reform. The combination of economic liberalization with a crisis of governability leads to industrial decline, with an unlimited waste of income and employment.

In this regard it is worth noting that the social cost of mismanaged policies impinges differently on the different participants. Multilateral financing agencies, for example, never place their capital at risk and can resort to "letters of intent" as a powerful instrument for guaranteeing the liberal agenda, without worrying 
about the level of activity. Government maladministration also leaves speculators untouched because the mobility of their investments enables them to make large profits without running major risks.

Thematic inconsistencies can also be observed. The government argues that structural issues are covered by the bill it has sent to Congress proposing several amendments to the constitution (the "Emendão"). However, the bill contains no mention of any measures to guarantee a permanent balance in the national accounts. There are no proposals for fiscal or budgetary reform to provide solid backing for the constitutional amendments under discussion. There is no reference to such urgent problems as the need to restructure the rules under which tax revenues are appropriated by the three tiers of government, to reorganize the links between the National Treasury and the monetary authorities, and to reform the social security system.

There is also an instrumental inconsistency. The government does not make harmonious use of its economic policy instruments. The Executive concentrates so hard on managing cash flow and controlling real interest rates that it fails to notice that favorable expectations are formed in light of structural changes. The effectiveness of economic policy has been jeapardized by delays in reprogranming the fiscal budgst and suggesting the replacement or even abolition of outdated tax and monetary policy instruments (Finsocial, PIS/PASEP, IOF tax on financial operations, TR, Fundão).

Nevertheless, it must be said that significant managerial improvements have recently occurred. After Marcilio Marques Moreira replaced Zélia Cardoso de Melo as finance minister in May 1991, the government at last began practising the liberalism it had been preaching for so long. It may be legitimate to ask, nonetheless, whether it is enough to state intentions cleary and show determination in following the logic of a market economy, in a situation where the general levei of prices must be stabilized at a politically viable cost.

The ten months since Marcilio took office can be divided into two phases. The first lasted until September 1991 and was characterized by a gradual elimination of price controls and decline in real interest rates. Although most economic actors accepted at face value his promise that there would be no more surprise packages, the financial market nonetheless signaled its lack of confidence in the local currency. With the first indications that the economic team was slow to get moving and inflation was again out of control, the black market dollar jumped from $\mathrm{Cr} \$ 800$ to $\mathrm{Cr} \$ 1,400$ overnight. The drain on international reserves was stopped by the firm determination shown by the monetary authorities, who refused to intervene in the foreign exchange market and manipulate the exchange rate. Exporters's liquidations of exchange contracts returned to normal and the black market dollar premium evaporated.

The outstanding feature of the second phase was confusion over the budget. Owing to lack of foresight and the absence of convincing achievements in the structural sphere, the government found itself at loggerheads with Congress over 
ratification of the federal budget and an emergency tax reform bill. Without the aproval of the two measures there could be no agreement with the IMF. As the 1991 parliamentary calendar breathed its last gasp, the Executive "magnanimously" held out to the opposition the irresistible carrot of a multiyear extension of the maturity of state and municipal debts in exchange for enactment of the two measures.

In January 1992 it was the Judiciary's turn to collide with the Executive. A number of lower courts having ruled that social security benefits and pensions be fully adjusted for inflation, the president convened an extraordinary session of Congress to pass a bill that raised the rate of employee taxes and contributions. The bill was at once thrown out and the federal court of audit (Tribunal de Contas) was consulted as to whether the extra funds could be found without any new taxes. After a fierce statistical divergence about the real degreee of structural imbalance in the social security system, it finally became evident that no governmental body can accurately say what state that system is in.

At this point a comparison with the Argentinian approach to stabiliz tion may be useful. The Menem administration is now conducting its third attempt at stabilization. The first was the Bunge y Born plan, starting when Menem took office and lasting until vecember 1989. It was interventionist and short-term in nature, contrasting with the government's announcement of liberal intentions, particularly for the financial market (dollar deposits and a free exchange market). Interest rates were capped and no deep-seated changes in public finances were proposed. The contradictory, meandering style of management soon led to a foreing exchange crisis.

From January 1990 to April 1991, the Erman Plan was in force (in versions I, II and III). The Executive branch of the federal government ran the economy in line with market principles: it rescheduled the internal and external public debts, sent bills to Congress proposing a new tax structure, consolidated changes in the financial market, cut import duties and stepped up the pace of privatization. This eliminated the risk of hyperinflation but was not enough to kill the expectation that inflation would remain high for some tinc. Inflation indeed continued to run at a high I ate, uncertainty persisted, and the recession proceeded. Anxiety abcut an imminent loss of speculative capital and the political instability caused by the steady drop in the level of activity led to resignation of the finance minister.

The Cavallo Plan, introduced in April 1991, pursued the same economic policy in overall terms but with one key new teature: a fixed rule for conversion of the Argentinian currency into US dollars. Monthly inflation, as measured by indices for exportable goods, has been close to zero since then and nominal interest rates paid by banks have stabilized at around $12 \%$ per annum. The main factor enabling Cavallo to topple inflation almost at once (from 5\%-25\% per month), in addition to his personal prestige, was the competence shown by his team. Expectations adjusted in an unprecedentedly short period possibly a few weeks to focus on the nominal goals set by the government. 
Upuntil the agreement with the IMF(February 1992), the Brazilian approach to stabilization was similar to the Erman phase in Argentina. It centered on all-out liberalism without any admixture of realism regarding managerial issues, i. e. the need for the government to state explicitly the nominal variables to which it was committed and to take an active role in implementing long-term structural reforms. There was only a shaiky political constituency in support of using recession as the main weapon, and even this support soon dwindled, as shown in the dollar crisis of September 1991 and the failure to pass higher taxes for social security in January 1992.

The February cabinet reshuffle, based on a explicit political alliance, signaled a strategy designed to neutralize reactions against the gradualistic approach to stabilization. However, no matter how far the government succeeds in obtaining political support and making up for past management errors, it is unlikely to be able to consolidate the downward inflationary trend without putting forward a clear and consistent plan of structural reform.

\section{THE LIBERALIZATION OF THE ECONOMY}

\subsection{Privatization ${ }^{4}$}

The Brazilian privatization experience began timidly with the National Debureaucratization Programme (July 1979), whose main goals were to strengthen market forces, put a stop to the indiscriminate creation of state enterprises and promote the conditions for transferring controls of SOEs to private enterprise. In 1981 (Decree 86215) and again in 1985 (Decree 91991), rules were set up for issuing SOEs stocks to the public, selling control to private-sector investors, and even shutting some of them down. An Interministerial Privatization Council was created. Some of these rules were changed in 1986 (Decree 93606), when the Council's decision-making powers were enhanced and the BNDES (National Development Bank) was made the agency in charge of executing the programme.

In 1988 (Decree 95886), the liberalization nrocess was intei isely reinforced, partly because the federal public sector was already on the verge of insolvency. The Interministe iial Privatization Council was abolished and a Federal Denationalization Council put in its place, with representatives of the stock markt, BNDES, labour and industry. The restrictions imposed under previous rulings with regard to participation by foreign capital in privatization were lifted.

Finally, law 8031 (December 1990) created the Programa Nacional de Desestatização, still in force. A Privatization Steering Committee was set up with 11 members, four representing the public sector and seven from the private sector. The BNDES remained in charge of implementation. Foreign investors were now allowed to acquire up to $40 \%$ of voting shares and $100 \%$ of nonvoting shares.

4 This section draws heavily on Mello (1991). 
Between 1979 and March 1990, when Collor took office, the privatization programme was confined to the devolution to private enterprise of companies that had been nationalized because of financial difficulties. This involved transfer to private ownership of 38 companies, which were sold both directly and by tender or auction, bringing in some US $\$ 824$ million to the government's coffers.

From now on, the plan is to sell SOEs that have always been federally-owned. The monopolies enshrined in the Constitution (oil, gas and ore extraction, and shipping lines) will be respected. 'The programme as it now stands has three main objectives: reduction of the public sector debt, reinforcement of market laws, and further democratization of companies. As of April 1991, privatization projects had been approved for 25 SOEs in the steel, petrochemical and fertilizer industries and their sale was expected to raise US $\$ 12$ billion. Payment can be made in the form of chirographary credits, public debt bonds, transfer of tittle to Cruzados Novos (old currency) held by the Central Bank, and other similar means.

The supply of credit (internal and external) for acquisition of these companies is potentially high, given the excessive indebtedness of the public sector. Funds deposited with the Central Bank (MYDFA), which are largely overdue external public debt, totaling US $\$ 35$ billion including both principal and interest, entitles the holder to participate in the privatization process with a $25 \%$ discount on face value - it is worth noting that on the secondary market these credits are traded with a discount of $65 \%$. The availability of funds for debt-equity swaps was reinforced by seizure of financial market investments during the 1st Collor Plan: the Central Bank holds a total of about US $\$ 17.5$ billion equivalent in Cruzados ivovos deposits (August 1991). Other public-sector debts which can be used for privatization include debentures issued by Siderbrás (the steel holding company), land reform bonds, and quotaholdings in the National Development Fund (FND). Interest groups have suceeded todelay privatization through Court decisions that questioned the windfall gains attributed to holders of currently depreciated assets.

The sum total of these credits is sufficient for acquisition of all federallyowned SOEs, estimated to be worth an aggregate US $\$ 60$ billion. The government should not have too much trouble with demand for shares in the most efficient companies, at least during this first stage. The Brazilian privatization experience began with the line of least resistance - first of all, devolution of nationalized companies to private ownership, and now the sale of the most profitable SOEs. The situation will be quite different when the time comes to privatize utilities and commercial SOEs with chronic deficits.

\subsection{Deregulation}

The "patrimonial" state in Brazil - in which the interests of the bureaucracy interlock witis those of the private sector - has deep historical roots. Portuguese 
laws played a more positive role in political organization than in trade and the private economy. The Ordenações (codification of existing laws) enacted by Manuel I and Felipe II of Portugal were fundamentally concerned with allocating public office, including military rank, as well as the property and privileges of the Church. Only after the architecture of administration had been erected did they move on to specify civil, criminal and procedural law. Knowledge of the rights inherent in sovereignty was not sought by studying the ancient customs of the Portugeses kingdom but borrowed from Roman law. The Ordenações were essentially a case of state intervention in the economy, business, shipping, domestic, commercial transactions, pricing, export embargos etc. (Faoro, i957, p. 64-65).

Strictly speaking, neither civil nor commercial law existed, but only administrative law. Thus the discipline imposed on individuals was noteconomically inspired but political in content. It did not serve the individual or commerce, rational and calculable in business terms, but the patrimonial state. The logic of laws and decisions was very distant from the impersonality and equality of values, for it was subordinated to the arbitrary rule of the Prince. England, the home of classical capitalism, uid not need to consolidate its laws in order to enable its economy to expand to plenitude; it dispensed with codes and with Roman law, for it was driven onwards by the force of its economy, grounded in private property, the context in which industrialization flourished. Thus, through centuries of ancestral assimilation, Brazil became the heir to a long history which dates back to the revolution of John of Aviz and the court of Manuel I (Faoro, 1957, p.66-69).

To cut costs and enhance the efficiency of the federal public administration, in the very first few days after President Collor took office he announced a radical change in ministerial structure. He reduced the number of ministries from 30 to only 12 , created secretariats, closed public bodies, eliminated posts in the top ranks of the administration, fired or laid off public employees, and sold government buildings, flats and vehicles. An initial evaluation indicates that the results were insignificant both financially and in terms of administrative reorganization not least in view of the difficulty of reforming institutions while macroeconomic instability continues to prevail. A great many of the mcasures announced were not implemented, and as many again will have to be revised or even abandoned.

In addition to the usual economic, political and legal obstacles, the reforms foundered because of insufficient preparation. No solution was found to the dilemma whether to increase the productivity of the civil service or improve low salaries. The Constitution guarantees job secutiry for civil servants, so that it is indeed difficult for the government to cut the size of its work force. The haste with which ministries were merged and autonomous authorities closed meant that the same functions are now performed by "super-ministries" or "supersecretariats" reporting directly to the presidency, and this has not led to significant savings or gains in effectiveness. 


\subsection{Liberatization 5}

In June 1990, the Executive announced its industrial and trade policy (Portuguese acronym: PICE), reproducing with a few differences the provisions of Decree-Law 2433 (May 1988) enacted by its predecessor, the Sarney administration. Its objective is "to enhance the efficiency of production and trade of goods and services by modernizing and restructuring industry". Its distinguishing feature is full integration between industrial policy and trade policy. According to the PICE, growth in imports will play a key role in fighting inflation because it will stimulate investment and sharpen competitiveness. Among the strengths of the PICE are the recognition that the effectiveness of industrial policy depends on the overall macroeconomic environment.

The problems faced by countries that try to liberalize their economies midway through a failed stabilization programme are well-known. When a stabilization programme is implemented simultaneously with measures to liberalize trade, this tends to put excessive pressure on the import-substitution sector. The changes made to industrial and trade policy since 1988 were designed to alter the development model that prevailed in the 1980s - a closed, uncompetitive, inefficient model that helped undermine the economic and technological dynamism of the decade.

A number of import restrictions were lifted, especially the tax on financial operations(IOF), duties for renovation of the merchant navy and port improvements, the obligation for companies to submit import schedules in advance, controls on import licenses, the similarity test, and compulsory financing of imports. The following measures made trade policy more open in 1990: (a) replacement of the crawling-peg devaluation system with a market-oriented system of floating exchange rates; (b) elimination of all special import schemes except drawback, the Manaus Free Zone and international agreements; (c) a phased-in reduction of all tariffs by 1994 , designed to achieve an a':erage tariff of $14.2 \%$ by then, with a small standard deviation (about $7.9 \%$ ). On average, nominal tariff protection will have dropped from $32.2 \%$ in 1990 to $14.2 \%$ in 1991. For sectors where Brazil has a competitive advantage, and for products without a locally-produced equivalent, a zero rate has been set; for sectors that will be afforded temporary protection, the rate will be $20 \%$.

The dynamism of the export sector derives above all from the behavior of the exchange rate throughout the liberalization process. In general it is advisable for liberalization to be preceded by a real devaluation so that adjustment by the import-substitution sector and the export sector can attenuate the impact of sharper foreign competition. In addition, macroeconomic stabilization should be guaranteed before the liberalization process is fully implemented.

5 This section relies on Silber (1991); Braga (1990a) and Braga (1990b). 
The flexible exchange policy introduced in the second half of 1990 was accompanied by the provisison of more credit to exporters. The lead time for negotiating foreing exchange contracts in advance of an export operation was increased, exporters were allowed to securitize bills of exchange and, faced with the high domestic rates of interest, exporters easily obtained external lines of credit to finance their activities.

However, a definitive recovery of exports is far from guaranteed. Where as the accumulated trade surplus in 1988 was US $\$ 19.1$ billion, it dropped to US $\$ 16.1$ billion in 1989, and to a mere US\$11 billion in 1990. In actual fact, exports have stayed flat at around US\$33 billion per annunm for the last three years, while imports have risen from US $\$ 14$.6 billion to US $\$ 20.3$ billion per annum. This weak performance was made possible only by suspension of foreign debt service. From now on it will be necessary to pay off the arrears and at the same time resume current services.

Trade policy has consolidated approximation with neighbors through the creation of regional blocs, in the hope that strategic partnerships can spread to other countries in the continent. The latest agreement relating to regional integration is the Southern Common Market (Mercosul), signed in 1986 by Brazil and Argentina, and later joined by Uruguay and Paraguay. (Treaty of Assunción 1990). Meanwhile, concessions are being made to other trading partners in the framework of the GATT round, with a view to eliminating disputes with developed nations. Examples are the effort to introduce stricter laws on intellectual property rights, and the commitment not to resort to Article 18b of the GATT, which permits the use of import restriction measures.

"Integration" can be seen as a step on the road to a common market, whereby independent states relinquish sovereignty in exchange for political participation in a multilateral forum. The issue therefore has broader implications than the immediate costs and benefits of trade liberalization and customs union. In addition to the evident advantages to consumers in the short run, now that domestic market protection has begun to be stripped away there will be qualitative gains from the regional harmonization of economic policies. The main benefit will be a boost to the dynamics of growth, and this more than compensates for potential disadvantages of a regional agreement.

This kind of broad perspective inspired the Treaty of Rome (1957) as Western Europe pulled irself together after World War II. The process began with a free trade zone, progressing to a customs union, and finally to the commom market. By contrast, in Latin America the Treaty of Montevideo (1960), which set up LAFTA (the Latin American Free Trade Association) - later renamed LAIA (Latin American Integration Association, 1981) - has never been much more than an expression of diplomatic intentions. Over the last three decades, the views that have prevailed are quite different from those that represented the accession of CEPAL's ideas to ruling circles - while the Cold War lasted, they were the views of the military governments and of the economists in public administration. Once 
the winds of democracy and liberalism had swept through the hemisphere, the countries of Latin America decided to move closer to other nations by setting up regional blocs with the aim of building strategic partnerships. The ambitious goal of Mercosul is to create a commom market by 1995 , as well as a regional parliament.

Brazil's complacency about the Mercosul effort contrasts strikingly with the enthusiasm of its partners. It is easy to explain why Uruguay and Paraguay are so keen on the initiative. Intraregional trade accounts for nearly $50 \%$ of their total trade, compared with a much lower $15 \%$ in the case of Argentina, and a mere 5\% in that of Brazil. Moreover, both countries are small, so that the ups and downs of domestic policies in their two big neighbors have swift and intense internal repercussions. Argentina puts a great deal of trust in Mercosul because it has already forged ahead with its own liberalization and stabilization process. The political strenght of tradicional sectors, especially the farmers and the financial community, helped the government to reduce average import tariffs to less than $10 \%$ (in Brazil they are still above $40 \%$ ) and conduct a stringent fiscal, monetary and foreing exchange adjustment.

Brazil is le committed to Mercosul: as well as having its own specific weight (in terms of a consumer market and industrial base) and a closed economy (imports account for less than 5\% of GDP) with high levels of protection for industry, the government has not succeeded in controlling the chaotic macroeconomic situation. It is a strategic error for Brazil to turn its back on the countries of the Southern Cone simply because $80 \%$ of its trading partners lie north of the Equator. It is an error, first of all, because the developed nations have already begun integrating economically, and in some cases politically. Any concessions from these blocs can only come now as a result of pressure by regional blocs. Thus, it is easier for Latin America to stop the recent decline in its share of international trade (from $8.5 \%$ to $3,5 \%$ ) by resorting to the advantages of economic integration. Indeed, the multilateral diplomacy of GATI negotiation has proved incapable of dealing with the key issues affecting the region, especially Brazil, such as farm subsidies in the industrial countries.

The main advantage of integration, however, it that it forces countries to harmonize stabilization policies in order to enter the commom market. Brazil is lagging behind in this regard, and it runs the risk of missing yet another opportunity to diminish macroeconomic uncertainty. Differently from the other Mercosul countries, Brazil's government has not yet produced a reliable plan of action. Harmonization of fiscal, monetary and foreign exchange policies requires uniform, stable rules of the game. Thus, before it concentrates on setting an agenda for the establishment of free movements of people, services and merchandise, a commom external tariff, standardized capital markets and homogeneous public services, the government must bring inflation down to tolerable levels. Not only is Brazil at the back of the queue but it offers no short-term prospect of normality whatsoever. 


\section{WHAT REMAINS TO BE DONE}

The federal government has not yet implemented a permanent fiscal adjustment. The measures taken in 1990 and 1991 to achieve a balanced budget were based on an increase in taxes and duties, making the tax system more regressive, inefficient and complex than it already was. They also excessively capped outlays for running costs and investment through cuts, restrictions and levies of doubtful legality and no legitimacy at all.

The way the federal Constitution determines how tax revenues are to be shared out is not compatible with the effort to modernize the structure of the budget. The burden of the obligations inherited from previous administrations, and the economic and social heterogeneousness of regions and classes, make it impossible to transfer most of the expenditures currently attached to the federal government to states and municipalities. Since the Constitution stripped the federal government of most of its traditional sources of revenue the Executive will have to continue resorting to new cumulative taxes not shared with subnational governments in order to guarantee a precariously balanced cash flow.

Very little has been done to pass legislation to minimize above distortions or to provide ordinary laws for the sections of the Constitution on public finance and the financial system. The current budgetary process involves groping in the dark for ways of adapting provisions in the new Constitution to the laws and traditions in force before 1988 . But the contradictions resulting from this process, aside from the normative vaccum, are very great. Provisions such as the $12 \%$ cap on real interest rates, aboliton of the National Monetary Council, the procedure for enacting budgetary laws, the ban on fiscal advances by the Central Bank and parliamentary intervention in the administration of public debt are only some of the most conspicuons examples of items that require urgent review and implementation.

\subsection{The Issue of Governability}

Would it be true to predict that a political or social crisıs will be the outcome of the growing insolvency of the federal government, and hence its increasing inability to provide services and guarantee republican institutions? Such an outcome is unlikely, the economic stagnation of the 1980s caused only gradual impoverishmet; the slow, steady decline in the standard of living in Brazil is not perceptible in a single generation. The impoverishment of the middle class, above all, has not had an intense impact on the majority. Moreover, freedom of expression and free speech are now complete, so that tension is more easily channeled. There is no censorship, nor are there radical groups (in thought or action) with any popular appeal:

However, if the government is to recover the nation's confidence, the legal and institutional framework must be modernized. Ambitious stabilization plans 
have been implemented but they have flouted a great many legal norms in the name of the "collective interest". The resurgence of inflation after so many doses of shock therapy obliges us to question the efficacy of these measures. It is therefore necessary to examine not only the legality but the legitimacy of economic packages.

Inflation, when high and chronic, is an illegal source of funds for the federal administration. Its illegality derives from the fact that there are no provisions in law for "inflatin tax". Moreover, this tax runs counter to the customary principles of taxation: equal rights to persons in equal positions, and neutral allocation of resources. On the other hand, stabilization packages based on shock treatment weaken the institutions of government by entailing vast and frequent changes to the rules in force. Provisional Measures, decrees and directives not only are often mutually conflicting, but seem to be designed to correct administrative errors or serve the interests of the federal Executive rather than to modernize institutions. When a state of anomie (lawlessness) becomes generalized, it raises the issue of the legitimacy of governments. The latter are often both "strong" and "weak" at the same time. They are strong when they legislate against the law, but they are weak when forced to resort to "inflation tax" to cover their costs.

Thus it is relevant to examine the concept of representation in light of the idea of a "social contract". The issue of governability can most usefully be discussed in such a context. Due importance must be afforded to the difficulty of applying the principle of majority rule to a socially and economically heterogeneous population that during most of its history has been suhmitted to oligarchic, populist, military or monarchical rule. It must be acknowledged that the rule of law and the legitimacy of government are frequently violated under the presidential system of representation, where the government can make as many mistakes as it likes for a predetermined perioci.

Bearing in mind the specific characteristics of the presidential system, the historical experience of Brazil and the heterogeneousness of its population, it would seem that effective government will be achieved only through a system of representation whereby the government consists as it were of a permanent assembly, as in the parliamentary system. In this kind of system, a succession of attempts to stabiize the economy and reform institutions would serve, as in a process of trial and error, to set up a stable Cabinet. Under parliamentary rule, government instability is neither frightening nor a threat to institutions - on the contrary, the principle that the government is secure for an indeterminate period makes for stronger institutions. 


\section{REFERENCES}

BRAGA, C. Primo: Liberalização Comercial e Estabilização. Informações FIPE, ago. 1990a.

.Us Policies and the Prospects for L.atin American Economic Integration. In: BAER, W. \& COES, D. (eds.),

US Policies and the Latin American Economies, New York: Praeger, 1990b.

FAORO, R. Os Donos do Poder. Porto Alegre: Globo, 1957, vol. 1.

LONGO, Carlos Alberto. Estado Brasileiro: Diagnósticos e Alternativas. Sāo Paulo: Atlas, 1990a.

. Crise e Revisão das Contas Públicas. In: VELL. OSO, J. P. Reis (ed ). Brasil: Agenda para Sair da Crise

- Inflação e Déricit. Rio de Janeiro: José Olympio, 1990b.

O Plano Collor em Perspectiva In: FARO, C. (ed). Plano Collor, Avaliação e Perspectivas. Rio de

Janeiro: Livros Técnicos e Científicos. 1990c.

. Plano Collor aos Noves Meses. In: VELL.OSO, J. P. Reis (ed.). A Retomada do Desenvolvimento

Rio de Janeiro: Nobel, 1991 a

A Questão da Govemabilidade In: FARO, C. (ed.). A Economia Pós Fiano Collor II. Rio de Janciro:

Livros Técnicos e Científicos, $1991 \mathrm{~b}$.

Brazil: Monetary and Financial System. In: EATWELL, J ; MILGATE, M \& NEWMAN, P. The New

Palgrave Dictionary of Money and Finance. London: Macmillan. 1992.

MEL.L.O, M. Figueira de O Projeto de Privatização Brasileira. Sāo Paulo: Faculdade de Economia e Administração. Universidade de São Paulo, 1991 (PhD Thesis).

PEL.AEZ, C. M \& SUZIGAN, Wilson. História Monetária do Brasil.. Rio de Janeiro: IPEA, 1976. (SÉrie Monográfica $n^{\mathbf{9}} 23$ ).

PREMCHAND, A El Estado y las Empresas Públicas: Relaciones Presupuestarias In: PREMCHAND, A. \& ANTONa Ya, A. L. Aspectos del Presupuesto Público. Washington: IMF.1988.

SENCHAGOV. V K. Restructuring the Financial System and its Influence on Economic Development. Proceedings of the 4.5th Congress of the International Institute of Public Finance. Buenos Aires: G Krause - Junk (Ed.), 1989.

SIL BER. S. D. Uma Avaliação da Política Brasileira de Comércio Exterior. Informações FIPE, maio, 1991.

SIMONSEN, M H. Inflação Gradualismo Versus Tratamento de Choque. Rio de Janeiro: APEC. 1970.

WERNECK. Rogério L. F. The Brazilian Privatization Program Rio de Janeiro: BNDES, 1991. (The First Year of the New Brazilian Privatization Program).

WORLD BANK. World Development Report 1988. Oxford Unviversity Press, 1988.

\section{SINOPSE}

Este artigo argumenta que o último plano de estabilização implantado com sucesso no Brasil coincidiu com as reformas institucionais realizadas em 1964/65, na administraçäo de Castelo Branco. Essas mudanças promoveram uma década de crescimento econômico acelerado, que terminou abruptamente. Erros de decisōes políticas em 1979/ 80. e durante a adminsitração Sarney contribuiram para a estagflação dos anos oitenta Desequilibrios macroestruturais geraram erosão da receita pública e aumento dos atrasados da dívida externa, comprometendo a eficácia das políticas monetárias e fiscais. Tentativas de estabilizar o nível de preços e de realizar mudanças institucionais durante o Governo Collor falharam em virtude da adoção de políticas incoerentes e da ausência de um plano de desenvolvimento coerente. Nāo sendo acompanhados por medidas permanentes de ajuste fiscal e reformas estruturais importantes, os avanços observados nos programas de liberalização, privatizaçào e destegulamentação podem ser abortados e conduzir a uma dispendiosa desindustrialização do País. 